\title{
Influence of Nature of Gene action in Sugarcane Germplasm accessions for yield and Quality Traits
}

\author{
M. Charumathi,* and N.V. Naidu \\ Regional Agricultural Research Station (ANGRAU) Anakapalle-531001
}

\begin{abstract}
A large diverse sugarcane germplasm is essential for sustained crop improvement. high heritability values were recorded for cane length, brix per cent, sucrose per cent and CCS per cent revealed the existence of narrow range of variability indicated the operation of non additive gene action in the inheritance of the characters. moderate estimates of GCV, PCV, GAM and heritability values were recorded for NMC and cane Yield indicated the importance of additive gene action in inheritance of the characters. The promising accessions could be utilized in the breeding programmes to develop high yielding genotypes for different traits.
\end{abstract}

Keywords: Germplasm, quality traits, gene action, sugarcane

\section{Introduction}

Collection, Conservation, characterization, maintenance and utilization of plant genetic resources are essential components of crop improvement programmes. Characterization, as defined by the International Board of Plant Genetic Resources means recording those characters which are highly heritable, can be easily seen by the eye and are expressed in all environments. The breeder has to periodically verify the trueness to label of clones in a germplasm collection. Hence database development of plant genetic resources collection, conservation, characterization, maintenance and utilization is of prime importance which should not be undermined. A large diverse germplasm is essential for sustained crop improvement. Clones from 31 expeditions during 1892 - 1985 have been deposited in India and United states (Ray Ming et al., 2006). These specific agronomic needs for pests and diseases resistance and to broaden the genetic base of commercially grown cultivars. It is expected that hybridization between the genotypes of two divergent clusters will lead to high heterotic effects and better performance in terms of yield and quality (Singh et al., 2004)

The six species of Saccharum and the related genera comprising of Erianthis, Miscanthis, Narenga and Sclerostachya form the basic genetic resources of sugarcane. Apart from the basic germplam several historical and commercial hybrids developed over the years at different cane breeding stations also form a potential gene pool for sugarcane improvement. This category also includes natural and induced mutants, aneuploids, some clones etc with specific attributes of importance in cane breeding. Consequent to the sustained efforts by several national and international agencies, a large collection of sugarcane germplasmn is available today representing the native variability available in the Saccharum comples. These collections have been conserved in the two World collections in USA and India. Nearly 4000 accessions of Saccharum, related genera and man - made historical and commercial hybrids are currently being maintained in India (Vijayan Nair, 2005).

Some of the varieties viz., CoT 8201, Co 62175, Co 419, Co 997, Co 7706, CoA 7602, CoA 8401 and 87A 298 with high yield and adaptability are being slowly removed from cultivation due to either susceptibility to pests and diseases or low sugar recoveries magnificent canes of yester years have became a measure specimens. Such clones need to be preserved to meet the future demand for development of varieties having desirable wide genetic base to wide stand over growing stains of pest complex. A successful breeding programme depends on the existence and hence there is a need to develop superior clones by using parents with wide genetic base. Obsolete varieties have to be maintained for future use. In the present investigation, the variability studies were conducted among the germplasm accessions of sugarcane.

\section{Materials And Methods}

The experimental material consisted of 91 sugarcane germplasm accessions including promising varieties and standards. They were grown in two rows of $5 \mathrm{~m}$ length in $80 \mathrm{~cm}$ between furrows adopting a seed rate of four three budded sets per meter. $\mathrm{RDF} 112 \mathrm{~kg} \mathrm{~N}+100 \mathrm{~kg} \mathrm{P}_{2} \mathrm{O}_{5}+120 \mathrm{~kg} \mathrm{~K} 2 \mathrm{O} / \mathrm{ha}$ was applied. Irrigation was accorded at 10 days intervals along formative phase of the crop. All the cultural practices were followed as per the recommendation. Data were recorded for NMC, cane yield, single cane weight, cane diameter, cane length, brix per cent sucrose per cent, CCS per cent and purity before harvest. SPAD Chlorophyll meter readings at 120DAP, red rot and smut diseases scoring was done on 0 to 9 scale (ICAR) at sixth month age of the crop. 


\section{Results And Discussion}

Per se performance of sugarcane germplasm accessions were identified for yield and quality traits were presented in Tables 1, 2 and 3. In the present study variation was observed for all the characters (Tables 1 and 2). The values ranged from 46.20 to 135.80 thousands/ha (number of millable canes), 44.00 to 132.00 t/ha (cane yield) 0.50 to 1.70 (single cane weight), Cane Girth (1.80 to 3.02), Cane length (1.60 to 3.8), brix per cent (15.00 to 24.02$)$, sucrose per cent (13.00 to 22.34$)$ CCS per cent (8.89 to 15.63$)$ and purity per cent (86.66 to 96.51) (Table 1 and Fig. 1).

Low genotypic coefficient of variation (GCV) and phenotypic coefficient of variation (PCV) and genetic advance as per cent of mean and high heritability values were recorded for cane length, brix per cent, sucrose per cent and CCS per cent revealed the existence of narrow range of variability indicated the operation of non additive gene action in the inheritance of the characters (Table 2). The present study was in conformity with the findings of Hapse and Repale (2001), Singh et al (2005), Sabitha (2007) Sirisha (2009) Anbanandan and Sarvanan (2010) and Charumathi et al (2012). While lower estimates of GCV, PCV, moderate estimates of GAM and high heritability values were recorded for single cane weight and cane diameter indicated the importance of both additive and non additive gene action in inheritance of the characters. The results are in conformity with the findings of Sabithaetal (2009), Anbanandan Sarvanan (2010) and Charumathi et al (2012) for the character, whereas moderate estimates of GCV, PCV, GAM and heritability values were recorded for NMC and cane Yield indicated the importance of additive gene action in inheritance of the characters. The results are in conformity with the findings of Jain et al. (2001), Gagandeep et al. (2004), Sabitha et al. (2009) and Anbanandanand Sarvanan (2010) for the character. High estimates of heritability and moderate genetic advance over mean were noted for the character. Similar results were reported by Jain et al.(2001), Singh et al. (2002), Rajabapa Rao (2002), Kumar et al. (2004), Doule and Balasudam (2006) and Charumathi (2011) for the traits. Simple selection procedures may help in bringing genetic improvement in these characters.

A total of 26 accessions for number of millable canes, 15 accessions for cane yield, 14 accessions for single cane weight, 27 accessions for cane diameter, 39 accessions for cane length, 45 accessions for brix per cent, 38 accessions for sucrose per cent and CCS per cent were found to be superior for yield and quality characters (Table 3). SCMR readings (35.00 to 49.50), red rot disease under nodal and plug methods of inoculation (0.00 to 9.00$)$ smut disease under artificially inoculated conditions (0.00 to 9.00) were noted during the crop growth period. The promising accessions could be utilized in the breeding programmes.

\section{References}

[1]. Alarmelu S, Shanthi RM, Nagarajan R, Hemaprabha G, Nair NV (2012) Introgression of improved germplasm of Saccharum spp in sugarcane breeding. International Symposium on New Paradigms in Sugarcane Research, Coimbatore, India, pp. 7-9.

[2]. Amalraj VA, Jebahas AW, Nair NV, Balasundaram N (2005) Introduced germplasm and varieties of sugarcane. Indian Journal of Plant Genetic Resources 8(1): 107- 108.

[3]. Anbanandan and Sarvanan, K. 2010. Genetic variability in interspecific and intergeneric progenies in sugarcane. Plant archives 10(2): 627-632.

[4]. Appunu C, Govindaraj P (2010) Evaluation of genetic potential of sugarcane interspecific hybrids (ISH) constituted from Saccharum complex. ThirdNational Congress on Plant Breeding and Genomics, Coimbatore, Tamilnadu, India, pp. 88-89.

[5]. Bakshi Ram (1990) Evaluation of sugarcane clones under coastal conditions of Andhra Pradesh. Indian Journal of Plant Genet Resources 3: 99-101.

[6]. Bakshi Ram, Hemaprabha G (1992) Genetic variability in interspecific progenies in sugarcane Saccharum spp. Indian Journal of Genetics and Plant Breeding 52:192-198.

[7]. Charumathi, M. 2011. Studies on selection indices in sugarcane (Saccharum officinarum L.). Ph.D (Ag.) Thesis submitted to the Acharya N. G. Ranga Agricultural University Hyderabad.

[8]. Doule, R.B and Balasundaram, N. 2006. Relative efficiency of cane characters in selection for cane yield in sugarcane (Saccharum spp. hybrid). Indian Journal of Genetics. 66 (4): 347-348.

[9]. Gagandeep, A.S., Mehla, M.S., Punia and Kadian, S.P. 2004. Studies on Variability, Heritability and Genetic gain for yield, its components and quality traits in sugarcane (Saccharum complex). Indian Sugar. 733-737

[10]. Hapase, R.S and Repale, J.M. 2001. Genotype x Environment interaction in Sugarcane. S.T.A 1. 63: 97-105.

[11]. Jain, P., Pal, R., Saini, M.L and Rai, L. 2001. Variability, heritability and genetic advance for yield attributes in sugarcane. Indian Sugar. 51(5): 321-324.

[12]. Jebadhas AW, Amalraj VA, Nair NV, Balasundaram N (2005) Introduction and Evaluation of Saccharum germplasm from Thailand. Indian Journal of Plant Genetic Resources 18(1): 106-107.

[13]. Kumar, C.K. 2004. Genetic Variability and Correlation Studies in Sugarcane (Saccharum officinarum L.) M.Sc. (Ag.) Thesis. Submitted to Acharya N.G Ranga Agricultural Universi Singh, A., Bhatnagar, P.K., Khan, A and Shrotria, P.K. 2002. Variability and heritability for cane yield its components and quality characters in sugarcane (Saccharum complex). Indian Sugar. 51(10) : 717-719

[14]. Nair NV (1989) Evaluation of new germplasm resources of sugarcane. Sugar Cane No. Supplement pp. 8-10.

[15]. Nair and Sreenivasan (1992) A study on the diversity of Saccharum officinarum L. ermplasm. Indian Jornal of Genetics 52: $39-44$.

[16]. Nair NV, Balakrishnan R, Sreenivasan TV (1998) Variability for quantitative traits in the exotic hybrid germplasm of sugarcane. Genetic Resources and Crop Evolution 45: 459-464.

[17]. Nair NV, Somarajan KG (2003) Diversity for Saccharum germplasm in Kerala. Plant Genetic Resources Newsletter 135: 40-43

[18]. Nair NV, Sekharan S (2009) Saccharum germplasm collection in Mizoram, India Sugar Tech 11: 288-291. 
[19]. Rajabapa Rao, V. 2002. Studies on stability and genetic parameters in selected genotypes of sugarcane (Saccharum spp). Ph.D thesis submitted to Acharya N G Ranga Agricultural University, Hyderabad pp : 296.

[20]. Ray Ming,Paul H.Moore,Kuo-Kaowu and ThomasL.Tew 2006 Sugarcane improvement through Breeding and Biotechnology ISBNO-471-73213-3

[21]. Sabitha, N. 2007. Genetic parameters and selection indices in sugarcane (Saccharum officinarum L.). M.Sc (Ag.). Thesis submitted to the Acharya N. G. Ranga Agricultural University Hyderabad.

[22]. Sabitha, N., Prasad Rao, K., Pandurangarao, C and Srinivasa Rao, V. 2009. Nature of Gene Action for yield and yield components in sugarcane. The Andhra Agricultural Journal. 56 (1) : 23-26.

[23]. Sahi BK, Bakshi Ram, Pramod Kumar (2002) Evaluation of sugarcane clones for ratoonability during winter months. Indian Journal of Sugarcane Tech 17(1-2):1-4.

[24]. Sirisha, M. 2009. Character association, path analysis and selection indices in sugarcane (Saccharum officinarum L. M.Sc.(Ag). Thesis submitted to Acharya N.G. Ranga Agricultural University, Hyderabad.

Table1. Per se performance of sugarcane germplasm accessions for yield and quality traits
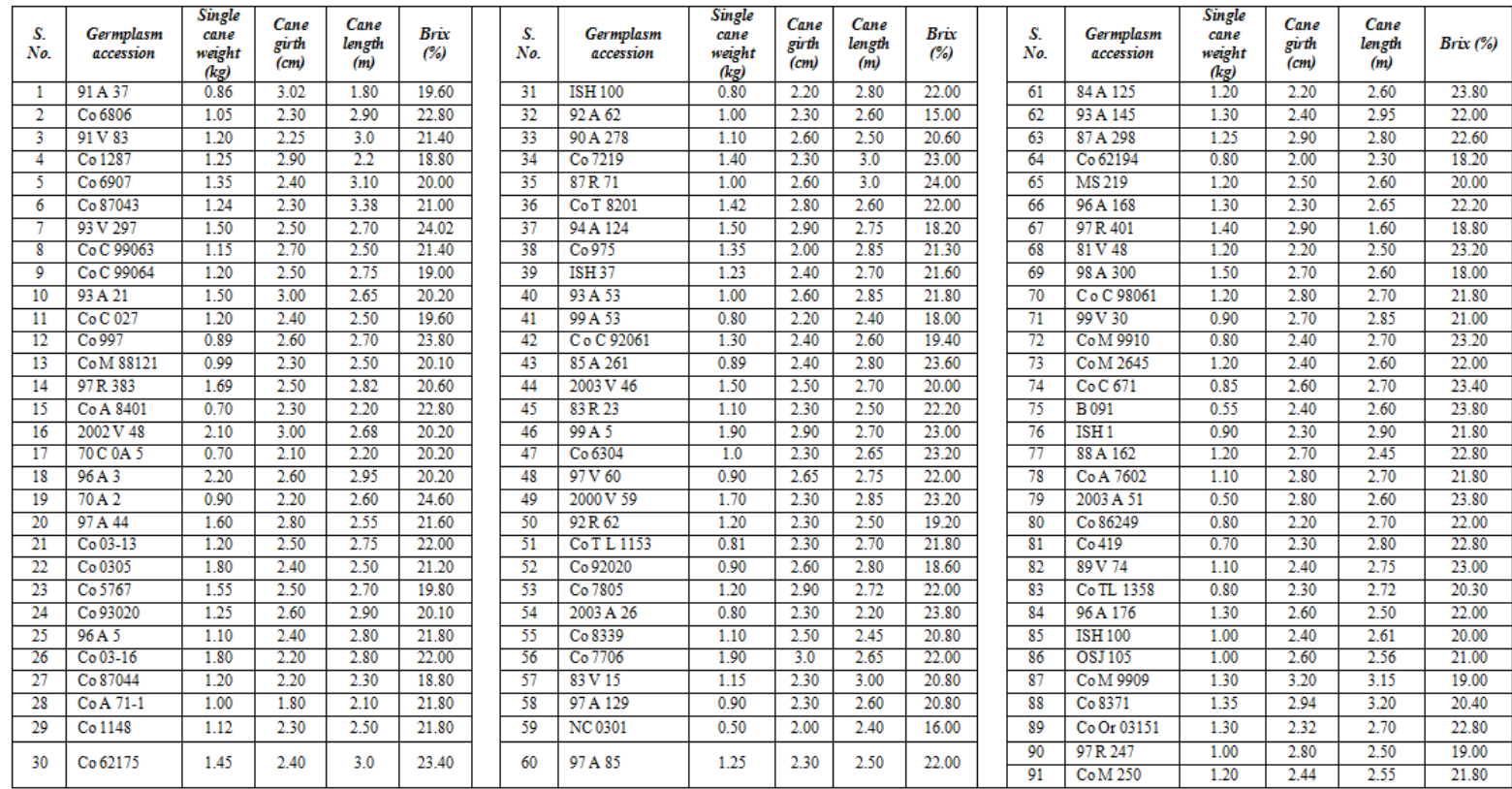

Table2 : Mean, variability, heritability, genetic advance and genetic advance as per cent of mean for cane yield, yield components and quality parameters in sugarcane germplasm accessions.

\begin{tabular}{|l|l|l|l|l|l|l|l|}
\hline Trait & Mean & Range & GCV $(\%)$ & PCV $(\%)$ & Heritability $\left(\boldsymbol{h}^{2)}\right.$ & Genetic Advance(GA) & GAM \\
\hline $\begin{array}{l}\text { NMC } \\
\text { thousands/ha) }\end{array}$ & & $46.20-135.80$ & 10.34 & 10.37 & 41.71 & 9.58 & 10.05 \\
\hline Cane yield (t/ha) & & $44.00-132.00$ & 10.88 & 15.00 & 45.00 & 16.82 & 12.85 \\
\hline $\begin{array}{l}\text { Single cane } \\
\text { weight (kg) }\end{array}$ & 1.16 & $0.50-1.70$ & 0.35 & 0.59 & 64.45 & 29.74 & 17.86 \\
\hline Cane girth (cm) & 2.47 & $1.80-3.02$ & 0.27 & 0.52 & 56.80 & 11.03 & 15.00 \\
\hline Cane length (m) & 2.65 & $1.60-3.38$ & 0.24 & 0.49 & 75.20 & 9.54 & 17.23 \\
\hline Brix (\%) & 21.33 & $15.00-24.02$ & 1.86 & 1.36 & 48.20 & 0.03 & 10.03 \\
\hline Sucrose (\%) & & $13.00-22.34$ & 4.08 & 5.45 & 77.24 & 1.92 & 1.36 \\
\hline CCS (\%) & & $8.89-15.63$ & 5.25 & 5.80 & 80.55 & & \\
\hline
\end{tabular}

Table 3. The following sugarcane germplasm accessions were identified for yield and quality traits

\begin{tabular}{|c|c|c|c|}
\hline S.No & Trait & $\begin{array}{l}\text { No. of } \\
\text { accessions }\end{array}$ & Germplasm accessions \\
\hline 1 & Single cane weight (kg) & 14 & $\begin{array}{l}93 \text { V 297, } 97 \text { R 383, } 2002 \text { V 48, } 96 \text { A 3, } 97 \text { A 44, Co 0305, Co 5767, Co 03-16, } \\
94 \text { A 124, } 2003 \text { V 46, } 99 \text { A 5, 2000 V 59, Co } 7706 \text { and } 98 \text { A 300, }\end{array}$ \\
\hline 2 & Cane girth $(\mathrm{cm})$ & 27 & $\begin{array}{l}91 \text { A 37, Co 1287, Co C 99063, } 93 \text { A 21, Co 997, } 2002 \text { V 48, } 96 \text { A 3, } 97 \text { A 44, } \\
\text { Co 93020, } 90 \text { A 278, } 87 \text { R 71, Co T 8201, } 94 \text { A 124, } 93 \text { A 53, } 99 \text { A 5, } 97 \text { V 60, } \\
\text { Co 92020, Co 7805, Co 7706, } 87 \text { A 298, } 97 \text { R 401, } 98 \text { A 300, C o C 98061, } 99 \text { V } \\
\text { 30, Co C 671, } 88 \text { A 162, Co A 7602, } 2003 \text { A 51, } 96 \text { A 176, OSJ 105, Co M 9909, } \\
\text { Co } 8371 \text { and } 97 \text { R 247. }\end{array}$ \\
\hline 3 & Cane length $(\mathrm{m})$ & 39 & $\begin{array}{l}\text { Co 6806, } 91 \text { V 83, Co 6907, Co 87043, } 93 \text { V 297, Co C 99064, Co 997, } 97 \text { R 383, } \\
96 \text { A 3, Co 03-13, Co 5767, Co 93020, } 96 \text { A 5, Co 03-16, Co 62175, ISH 100, } \\
\text { Co 7219, } 87 \text { R 71, } 94 \text { A 124, Co 975, ISH 37, } 93 \text { A 53, 85 A 261, 2003 V 46, } 99 \\
\text { A 5, } 97 \text { V 60, 2000 V 59, Co T L 1153, Co 92020, Co 7805, 83 V 15, } 93 \text { A 145, } \\
87 \text { A 298, C o C } 98061 \text {, } 99 \text { V 30, Co M 9910, Co C 671, ISH 1, Co A 7602, Co } \\
\text { 86249, Co 419, } 89 \text { V 74, Co TL 1358, Co M 9909, Co 8371, Co Or 03151. }\end{array}$ \\
\hline 4 & Brix (\%) & 45 & Co 6806, 93 V 297, Co 997, Co A 8401, 70 A 2, 97 A 44, Co 03-13, 96 A 5, Co \\
\hline
\end{tabular}




\begin{tabular}{|c|c|c|c|}
\hline & & & $\begin{array}{l}\text { 03-16, Co A 71-1, Co 1148, Co 62175, ISH 100, Co 7219, } 87 \text { R 71, Co T 8201, } \\
\text { ISH 37, } 93 \text { A 53, } 85 \text { A 261, 83 R 23, } 99 \text { A 5, Co 6304, 97 V 60, 2000 V 59, Co T } \\
\text { L 1153, Co 7805, } 2003 \text { A 26, Co 7706, } 97 \text { A 85, } 84 \text { A 125, } 93 \text { A 145, } 87 \text { A 298, } \\
96 \text { A 168, } 81 \text { V 48, C o C 98061, Co M 9910, Co M 2645, Co C 671, B 091, ISH } \\
\text { 1, } 88 \text { A 162, Co A 7602, } 2003 \text { A 51, Co 86249, Co 419, } 89 \text { V 74, } 96 \text { A 176, ISH } \\
\text { 100, Co Or } 03151 \text { and Co M 250. }\end{array}$ \\
\hline 5 & $\begin{array}{l}\text { Sucrose }(\%), \quad \operatorname{CCS}(\%) \\
\text { and Purity Per cent }\end{array}$ & 38 & $\begin{array}{l}\text { Co6806,91V83,Co87043,93V297,CoC99063,CoA8401,2002V48,97A44,Co0313, } \\
\text { Co5767,96A5,Co0316,CoA711,CA2612003V46,99A5,Co6304,97V602000V48, } \\
\text { Co1148,Co62175,ISH100,Co7219,87R71,Co975,93A53,85A261,2003V46,99A5, } \\
\text { Co6304,97V60,2000V59,2003A26,84A125,93A145,87A298,96A168,CoC98061, } \\
\text { 99V30,CoM9910,CoM265,Coa7602,CoOr 03151 and CoM250. }\end{array}$ \\
\hline
\end{tabular}

Fig -1: Pie diagram of sugarcane germplasm accessions for yield quality traits

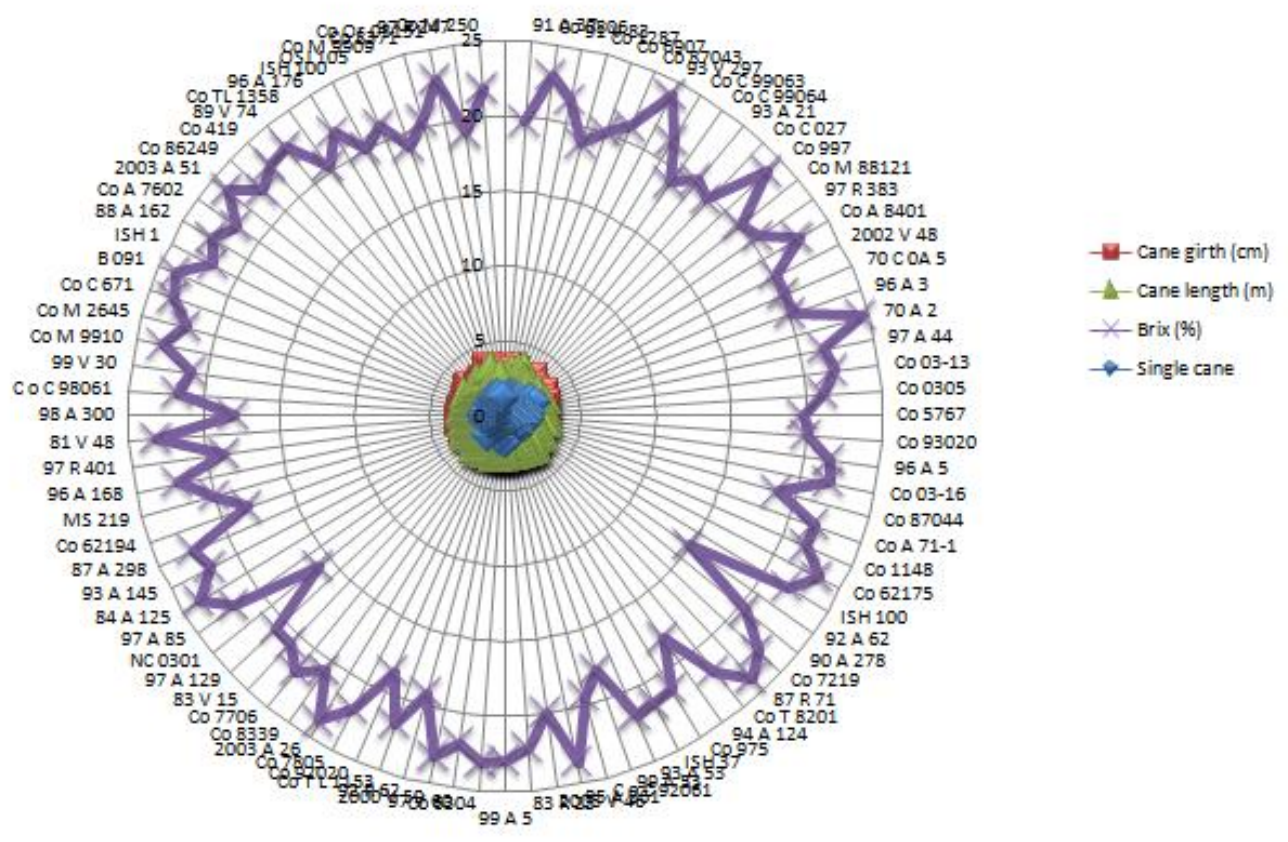

